Paedagogia Christiana

2/28 (20I I) - ISSN 1505-6872

\author{
Jeremiasz Jan Anchimiuk* \\ Warszawa
}

\title{
Bóg i stworzenie w teologii prawosławnej
}

Pytanie o pochodzenie świata i o stosunek Boga do świata jest jednym z głównych pytań stawianych w teologii, filozofii i naukach przyrodniczych na przestrzeni wieków. Jeśli chodzi o pogląd prawosławny na ten temat, to jest on, oczywiście, określony przez pojmowanie biblijnej wizji stworzenia świata i stosunku Boga do stworzonego świata przed grzechem pierworodnym i po popełnieniu tego grzechu. Prawosławna kosmologia i soteriologia nie różni się zatem w punkcie wyjścia od teologii rzymsko-katolickiej lub protestanckiej. Należy jednak uwzględnić fakt, że w interpretacji tekstu Biblii występują różnice, i to niekiedy bardzo głębokie. Wydaje się, że odczytanie przesłania Biblii w Kościele Prawosławnym jest mocniej niż w Kościołach zachodnich określone przez myśl Ojców i Nauczycieli Kościoła oraz przez liturgiczny kontekst, uwzględniający doświadczenie duchowe wielu pokoleń świętych ascetów.

Poglądy Orygenesa, nauczanie wielkich Kappadocejczyków, św.św. Bazylego Wielkiego, Grzegorza Teologa, Grzegorza z Nyssy oraz późniejszych Ojców, jak na przykład św. Maksyma Wyznawcy, św. Symeona Nowego Teologa, św. Grzegorza Palamasa, stanowią nie tylko stały element uprawiania i nauczania teologii. Myśl Ojców Kościoła, a lepiej należałoby powiedzieć doświadczenie życia Kościoła, została zawarta w tekstach liturgicznych, które są jedyną w swoim rodzaju poezją, w sposób niezwykle pre-

* Ks. abp prof. dr hab. Jeremiasz Jan Anchimiuk, rektor Chrześcijańskiej Akademii Teologicznej w Warszawie, kierownik Katedry Pisma Świętego Nowego Testamentu na Wydziale Teologicznym ChAT. 
cyzyjny wyrażającą myśl teologiczną Kościoła, formułowaną od początku jego istnienia. Należy dodać, że bogactwo tekstów liturgicznych w Kościele Prawosławnym jest ogromne. Nabożeństwa każdego dnia roku oprócz stałych elementów mają własne teksty, używane tylko w tym dniu.

Wypowiedź teologiczna, zmierzająca do określenia prawosławnego poglądu na dany temat, powinna zatem uwzględniać nauczanie Pisma Świętego, Ojców Kościoła, doświadczenie świętych ascetów, treść i formę nabożeństw.

Jeśli chodzi o temat stanowiący tytuł tego przyczynku, to za wzór dzieła uwzględniającego wymienione zasoby myśli w tym zakresie może być postawiony rozdział X, noszący tytuł List dziewiaty: Stworzenie, genialnego wręcz dzieła o. Pawła Florenskiego pod tytułem Filar i Podpora Prawdy ${ }^{1}$.

Każda teologiczna wypowiedź na temat stosunku Boga i stworzenia będzie z konieczności koncentrowała się wokół aktualnego stanu stworzenia widzialnego i niewidzialnego oraz pytania, w jakim stopniu stan aktualny odpowiada temu stworzeniu, które jest dziełem Boga. W przypadku braku potwierdzenia tej zgodności powstaje pytanie o możliwość i drogi powrotu do stanu pierwotnego, czy też do stanu innego, zgodnego z wolą Bożą.

\section{1. Świat i czlowiek przed i po grzechu pierworodnym}

\subsection{Konieczność korekty interpretacji Hexameronu}

Podstawowym twierdzeniem o stosunku Boga do świata jest wypowiadana wielokrotnie w Piśmie Świętym myśl o stworzeniu świata przez Boga. Wszystko, co istnieje, zostało stworzone przez Boga. Tak mówią pierwsze słowa Biblii.

Interpretacja Hexameronu w teologii prawosławnej pozostaje pod wielkim wpływem myśli św. Bazylego Wielkiego. Istotną jej cechą jest akcentowanie uniwersalnego, w znaczeniu wszechświatowego, aspektu stworzenia. Bóg stworzył wszystko, co istnieje. Ziemia jest cząstką Wszechświata. Widać tu wyraźnie, jak bardzo myśl tego Ojca Kościoła różni się od prymitywnego werbalistycznego pojmowania tekstu Pisma, tak często spotykanego nie tylko w szkolnych podręcznikach.

Św. Bazyli potrafił łączyć wierność tekstowi Pisma z dostrzeżeniem konsekwencji tej wierności. Przyjmuje dosłownie stworzenie światła przed

${ }^{1}$ Свящ. Павел Флоренский, Столп и Утверждение Истины. Опыт православной феодицеи в двенадиати письмах, Москва 1914. W jęz. polskim: P. Florenski, Filar i Podpora Prawdy. Próba teodycei prawosławnej w dwunastu listach, Warszawa 2009. 
stworzeniem słońca, co prowadzi go do wniosku, że nie tylko słońce jest źródłem światła we Wszechświecie. A to z kolei pozwala mu na wytłumaczenie możliwości zaistnienia ,zieleni” i ,ziela, wydającego nasienie i drzewa owocowego" już w trzecim dniu stworzenia, przed powstaniem słońca, księżyca i gwiazd w czwartym dniu tworzenia świata ${ }^{2}$.

Pod wpływem myśli Ojców Kościoła teologia prawosławna rozwinęła biblijne pojmowanie materii. Stworzona przez Boga materia jest „niewidzialna" i ,nie posiada formy”. W tym pojmowaniu zarówno teologia patrystyczna, jak i współczesna teologia prawosławna idzie za określeniem materii zawartym w przekładzie LXX. Hebrajskie tohu vabohu zostało w LXX przełożone właśnie jako $\alpha o \rho \alpha \tau o \varsigma \kappa \alpha \iota ~ \alpha \kappa \alpha \tau \alpha \sigma \kappa \varepsilon v \alpha \sigma \tau o \varsigma$. Ziemia niewidzialna nie posiadająca formy jest raczej pierwotną materią, z której powstały galaktyki, czarne dziury kosmiczne, przestrzeń, czas, widziane gołym okiem gwiazdy i planety, w tym również nasza Ziemia. O. Sergiusz Bułgakov w swoim teologicznym komentarzu do Apokalipsy identyfikuje tę pierwotna materię ze znajdującym się przed tronem Wszechmocnego „morzem szklistym, podobnym do kryształu" (Ap 4, 6) ${ }^{3}$.

Ziemi stworzonej przez Boga nie należy zatem utożsamiać z naszą planetą i z tym, co potocznie nazywamy ziemią. To pojmowanie biblijnej ziemi w połączeniu z twierdzeniem, iż Hexameron przedstawia powstanie świata z punktu widzenia ogarniającego cały Wszechświat, zmusza do rewizji wielu elementów tradycyjnych wykładni biblijnego obrazu stworzenia. Komentarze, wypowiedzi dogmatyczne i różnego rodzaju podręczniki w zbyt wielkim stopniu kierowały się obiegowymi wyobrażeniami swoich czasów, w tym też poglądami naukowo-filozoficznymi, i przypisywały Biblii treści, których w niej wcale nie ma. Przykładem może być bezsensowny, gdyż pozbawiony biblijnych podstaw, spór o teorię ewolucji, w którym często partnerzy dyskusji nie dostrzegają, że Hexameron wyraźnie wskazuje, iż Stwórca obdarza „,ziemię” czyli materię zdolnością ,wydania” zieleni (Rdz 1, 11-12) i innych stworzeń, czyli zdolnością tworzenia.

\subsection{Ciało czlowieka}

Podobnie jest z pojmowaniem ciała człowieka i miejsca raju. W modlitwie św. Bazylego Wielkiego na Liturgii Eucharystycznej po „Święty, Świę-

${ }^{2}$ B. de Cesaree, Homelies sur L'Hexameron, w: Sources Chretiennes, Texte Grec, Introduction et Traduction de Stanislas Giet, Paris 1949, s. 170n.

${ }^{3}$ С. Булгаков, Апокалипсис Иоаннаю Опыт догматического истолкования, Paris 1948, s. 47. 
ty, Święty jest Pan Zastępów...” znajdujemy słowa o tym, że człowiek „nie usłuchał Boga Prawdziwego, Który go stworzył, lecz poddawszy się podszeptowi węża i będąc poddany śmierci przez własne przestępstwa" został przez Boga wygnany z raju do ,tego świata". W modlitwie tej uwagę zwraca wskazanie na dwa powody grzechu pierworodnego: jest to „podszept”, inaczej pokusa, węża i ,własne przestępstwa”. Warto zwrócić uwagę na to, że grzech został popełniony z dwóch powodów.

Jest to, oczywiście, niezwykle interesujące, dla naszego tematu, jednak warto podkreślić czynione przez św. Bazylego odróżnienie raju od „tego świata”. Rajem była cała „ziemia” stworzona przez Boga. Przy czym św. Bazyli nie utożsamia tej ziemi z „ziemią” w obecnym znaczeniu tego słowa. Raj nie należy zatem do tego, naszego, świata. Nie ma sensu umieszczanie raju gdziekolwiek na naszej planecie Ziemi. Nasza „ziemia” stała się miejscem pobytu człowieka dopiero po grzechu. W wyniku grzechu zmienione też zostało nasze ciało. Bóg dał nam ciało ze „skór zwierzęcych”, czyli nasze ciało upodobniło się do ciała zwierząt. Przed grzechem było inne.

Według św. Grzegorza z Nyssy pierwotne ciało człowieka składało się

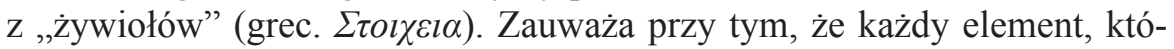
ry widzimy nawet w obecnym ciele człowieka, w oderwaniu od całości nie może być uznany za ciało. Kolor, ciężar, objętość są w oderwaniu od całości pojęciami teoretycznymi ${ }^{4}$.

Tym, co decyduje o ciele, jest - w opinii o. Pawła Florenskiego - indywidualność, „która przenika każdy organ człowieka”. Nadaje ona jednolitość ciału ludzkiemu. ,... Istnieje jakaś odpowiedniość między najsubtelniejszymi właściwościami struktury organów i najmniejszymi poruszeniami charakteru osobowego".

Dlatego - pisze ten teolog - im bardziej rozmyślamy nad pojęciem ciata ludzkiego, tym silniej dochodzi do głosu konieczność przejścia od ontologicznych peryferii ciała do jego ontologicznego centrum, tzn. do tego ciała, bez którego do wszystkich owych organów odnosiłoby się wyłącznie pojęcie homousia, ale nigdy nie homoiousia. Ów korzeń jedności ciała, owo ciało w ciele, owo ciało par excellence, jest ciałem, które nas tutaj interesuje. To, co zazwyczaj nazywa się ciałem, nie jest niczym więcej, jak powierzchnia ontologiczną; tymczasem mistyczna glębia naszej istoty znajduje się poza nią, po drugiej stronie owej powtoki $i^{5}$.

4 Л. П. Карсавин, Св. Отцы и Учители Церкви, Раскрытие православия в их творениях, Paris (bez daty wydania), s.191, por. także s. 196.

${ }^{5}$ P. Florenski, dz. cyt., s. 214-215. 
To wyrastające $\mathrm{z}$ opartych na Biblii i na koncepcjach filozoficzno-psychologicznych rozważanie o ciele człowieka pozwala na twierdzenie, że mimo „skór zwierzęcych” włożonych na człowieka przez Boga po upadku, stworzone przez Boga ciało człowieka nie zostało mu odebrane. „Skóry” tylko przykrywają prawdziwe ciało człowieka, ale już nawet w Starym Testamencie niektórzy ludzie dostąpili stanu pozbycia się tych „skór” i zostali „zabrani do Boga”. Należeli do nich Henoch i prorok Eliasz (Rodz 5, 24; 2 Krol 2, 1-13). Pan nasz Jezus Chrystus zmartwychwstał w ciele. Słów Ewangelii Łukasza (24, 41-43) o tym, że Chrystus widząc zwątpienie Apostołów polecił, by dano Mu „,oś do jedzenia” i gdy „podali Mu kawałek pieczonej ryby wziął i jadł wobec nich" nie należy traktować jako poetycką przesadę. Odnosi się to także do przezwyciężenia niewiary Tomasza poprzez dotknięcie ran w zmartwychwstałym ciele Chrystusa (Jn 20, 24-29).

\subsection{Asceza}

Takie pojmowanie ciała prowadzi do pytań o sposób zrzucenia „skór zwierzęcych" i odzyskania pierwotnego, przez Boga stworzonego ciała. Odpowiedzią Kościoła prawosławnego jest wezwanie do ascezy jako drogi, która czyni możliwym uświęcenie nawet tego, jeszcze „zwierzęcego”, ciała. Albowiem nawet to ciało, które obecnie nosimy, może dostąpić przemiany, przebóstwienia, wyrażającej się w całkowitej lub częściowej niezniszczalności, która trwać będzie aż do powtórnego przyjścia Chrystusa.

Wezwanie do ascezy w prawosławnym ujęciu jest niczym innym, jak tylko realizacją wezwania św. Apostoła Pawła: „odrzućcie wcześniejszy sposób życia starego człowieka, niszczonego przez oszukańcze pożądliwości, i odnówcie ducha myślenia waszego i przyobleczcie się w nowego człowieka, stworzonego na wzór Boga w sprawiedliwości i świętości prawdy" (Ef 4, 22-24).

„Sposób życia starego człowieka” ( $\alpha v \alpha \sigma \tau \rho o \varphi \eta ~ \tau o v ~ \pi \alpha \lambda \alpha l o v ~ \alpha v \theta \rho \omega \pi o v)$, przejawiony przez Adama i Ewę, wyraził się w zerwaniu i spożyciu owoców z drzewa w celu poznania dobra i zła, co miało dać im boskość („,będziecie jak Bóg") ${ }^{6}$. Cel ostateczny, w teologii prawosławnej określany jako przebóstwienie, był postawiony przed człowiekiem przez Boga. Dlatego Bóg

${ }^{6}$ Por. C. Westermann, Genesis. Kapitel 1-11, Neukirechen 1974, s. 328. C. Westermann przekłada ostatnie słowa Rdz.3, 5 na język niemiecki jako „und ihr werdet sein wie Gott, wissend Gutes und Böses” - „będziecie jak Bóg, znając Dobro i Zło”. Ten sposób przekładu teksu hebrajskiego podkreśla, iż pokusa polegała na pragnieniu osiągnięcia stanu Bożego, równości z Bogiem. 
dał mu kluczowe miejsce w stworzeniu. Ps 82, 6 głosi wolę Boga Stwórcy: „Ja rzekłem, Bogami jesteście”. Sam Chrystus wypowiada słowa tego psal$\mathrm{mu}$ w dialogu po uzdrowieniu ślepego od urodzenia (Jn 10,34). Metropolita Kallistos (Ware) pisze: „Według słów św. Bazylego Wielkiego człowiek nie jest nikim innym jak stworzeniem, które otrzymało nakaz stania się bogiem". Także św. Atanazy Wielki - zauważa Kallistos - powiedział o Chrystusie: „Stał się On człowiekiem, aby człowiek mógł stać się bogiem”"

Błąd Ewy i Adama polegał na tym, że poddali się ,podszeptowi” węża jakoby Bóg nie chciał ich dopuścić do staniu „bycia jak Bóg”. Dlatego sięgnęli po owoce, sądząc, że poprzez ich spożycie osiągną stan boskości wbrew Bogu. Inaczej mówiąc, pragnęli zdobyć boskość, odchodząc od Boga Stwórcy, Dawcy Życia. Poddali się żądzy jedzenia, żądzy „rozkoszy oczu” i żądzy „zdobycia wiedzy”. Stworzona materia, bo i drzewo, i owoce są przecież materialne, miała według Adama i Ewy dać im wartości duchowe.

Zniewolenie przez pragnienie jedzenia, „rozkosz oczu” i pragnienie poznania sięgnęło głębin istoty człowieka. Wyrwanie się z tej niewoli wymagało przeciwstawienia się tym żądzom. Bóg nie opuścił swojego dzieła, człowieka i całego stworzenia, również i w tej sytuacji. Poprzez Wcielenie, Krzyż i Zmartwychwstanie ukazał, że jest nie tylko Wszechmocny, ale i Miłością, sięgającą wyparcia się Siebie Samego (Filip 2, 8). Tak Bóg odpowiedział na sugestię węża, iż Bóg nie chce, by człowiek był jak Bóg, znający dobro i zło $(\operatorname{Rdz} 3,5)$.

Dlatego człowiek, pragnący społeczności z Bogiem, żądzy jedzenia przeciwstawia powstrzymywanie się od pokarmów, żądzy „rozkoszy oczu” przeciwstawia spowodowany przez jego postępowanie obraz niszczenia, przemijania, rozkładu Bożego stworzenia $(\varphi \theta o \rho \alpha \mathrm{Rz} 8,21)$, żądzy wiedzy przeciwstawia pragnienie „bycia z Bogiem” (a nie wyrastającego z zazdrości i pychy bycia ,jak Bóg").

Droga ascezy jako powrotu do Boga nie może oznaczać negatywnego stosunku do stworzonego przez Boga świata materialnego. Kościół zdecydowanie odrzucił poglądy tych, którzy traktowali ciało człowieka jako zło i zakazywali chrześcijanom małżeństwa oraz spożywania mięsa i wina. 51 kanon apostolski nakazuje pozbawiać godności tych duchownych, którzy „poniechają małżeństwa, mięsa i wina, czyniąc to nie dla trudu wstrzemięźliwości, lecz z pogardy, nie pomnąc tego, że wszystko, co zostało stworzone, jest dobre" ${ }^{8}$. Tak widziana asceza jest przejawem odpowiedzialności czło-

${ }^{7}$ G. I. Mantzaridis, Przebóstwienie człowieka. Nauka świętego Grzegorza Palamasa w świetle tradycji prawosławnej, Lublin 1997, s. 14.

${ }^{8}$ A. Znosko, Kanony Kościoła Prawosławnego, Hajnówka 2000, s. 23. 
wieka za całe Boże stworzenie. Jest więc drogą powrotu człowieka na to miejsce, które zostało mu dane przez Boga od chwili stworzenia.

W rozważaniach na temat znaczenia ascezy dla losów stworzenia o. Paweł Florenski przytacza myśl św. Izaaka Syryjczyka: „Doskonałość wszelkiej ascezy, według tego Ojca pustyni, zawiera się w ... skrusze serca, w czystości i w doskonaleniu siebie". Życie ascety jest oddane pokucie, która jest „sercem skruszonym i pokornym”. Pokora zaś jest „śmiercią dla wszystkiego”, jest „sercem współczującym”. A „serce współczujące” jest „,̇arem serca skierowanym do całego stworzenia, do ludzi, do ptaków, do zwierząt, do demonów i do całego stworzenia". Asceta modli się za wszystkich i wszystko, ,za stworzenia pozbawione mowy (ros. безсловесных), i za wrogów Prawdy, i za tych, którzy mu szkodzą, by oczyścili się i ocaleli" Modli się także ,za istoty pełzające” (ros. и об естестве пресмыкаюшихся - chodzi o węże, jest to wyraźne nawiązanie do węża z Rdz 3, 1-5 - uwaga abpa Jeremiasza) ${ }^{10}$.

\subsection{Odpowiedzialność za stworzenie}

W rozważaniach teologów prawosławnych na temat grzechu człowieka i skutków grzechu centralne miejsce zajmuje myśl Apostoła Pawła, wypowiedziana w Liście do Rzymian 8, 18-23. Zawarty w tym fragmencie obraz stworzenia ogarnia cały Wszechświat. Na pierwszym miejscu Apostoł wymienia fakt uzależnienia stanu stworzenia od stanu człowieka. Stan stworzenia opisany jest słowami ,... całe stworzenie ciężko wespół wzdycha i cierpi wspólne bóle rodzenia aż do teraz" (Rz 8, 22). Zakończenie tego stanu cierpienia stworzenia nastąpi po „objawieniu synów Bożych”.

Zwrócić należy uwagę na personifikację stworzenia. Stworzenie „ciężko wespół wzdycha” ( $\sigma v \sigma \tau \varepsilon v \alpha \zeta \varepsilon l)$ i „,cierpi wspólne bóle rodzenia” ( $\sigma v v \omega \delta \imath v \varepsilon \imath)$. Z wiersza 22 wynika, że zależność losów stworzenia od człowieka nie pozbawia stworzenia zdolności ,rodzenia”. Ta wypowiedź nawiązuje w sposób oczywisty do mocy twórczej, darowanej pierwotnej materii przez Stwórcę, o czym wyraźnie świadczy Hexameron. Realizacja tej zdolności stworzenia jest jednak obecnie związana z bólem.

Grzech człowieka posiada więc wymiar kosmiczny. Całe stworzenie zostało przez człowieka skierowane na drogę przemijania i unicestwienia

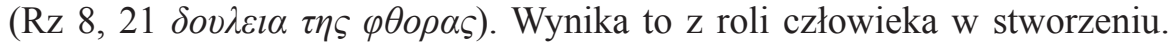
Człowiek jest ostatnim, najwyższym dziełem rąk Bożych, powołanym „do

\footnotetext{
${ }^{9}$ P. Florenski, dz. cyt., s. 252-253.

10 Tamże, s. 315.
} 
rozradzania się”, „rozmnażania się”, „,napełniania ziemi”, „czynienia jej sobie poddaną", ,panowania nad rybami morskimi i nad ptactwem niebios, i nad wszelkimi zwierzętami, które się poruszają po ziemi” (Rodz 1, 28). Ta rola człowieka nie uległa zmianie. Losy całego stworzenia są zależne od stanu człowieka. Grzech człowieka przynosi stworzeniu cierpienie. Świętość zaś przynosi całemu stworzeniu radość powrotu do Boga.

Wygnanie z raju nie oznacza zatem odwrócenia się Boga od swojego stworzenia, tzn. od człowieka i wszystkiego, co istnieje. Oznaczałoby to bowiem skazanie na całkowite zniszczenie tego, co Bóg stworzył. Jest to myśl nie do pogodzenia $\mathrm{z}$ twierdzeniem, że Bóg stworzył świat, pragnąc obdarzyć radością życia to, co nie istnieje. Św. Grzegorz z Nyssy wypowiedział tę myśl w ten sposób, że każde stworzenie jest cząstkowym odzwierciedleniem Boga. Według niego, w każdym stworzeniu jest Bóg, Który wszystko przenika, wszystko obejmuje, we wszystkim przebywa. Nawet więcej, jakaś cząstka „natury” Bożej znajduje się we wszystkim, co istnieje i nie poddaje się ani władzy czasu, ani przestrzeni ${ }^{11}$.

W cytowanej wyżej modlitwie św. Bazylego znajdujemy również takie słowa: „...nie porzuciłeś bowiem na zawsze swego stworzenia, które stworzyłeś, Dobry, ani też nie zapomniałeś o dziele rąk Twoich, ale nawiedziłeś wieloma sposobami według wielkiego Twego miłosierdzia ... posłałeś proroków ... na pomoc dałeś prawo, postawiłeś Aniołów jako Stróży, a kiedy nadeszła pełnia czasu, przemówiłeś do nas przez samego Twego Syna, przez którego też stworzyłeś wieki...”.

Twórcza miłość Boża nie oznacza więc zniewolenia. Człowiek, a wraz z nim całe stworzenie, może się od Boga oddalić. Oddalenie się od Boga oznacza jednak zniewolenie przez nicość. Adam z Ewą po zjedzeniu owocu $\mathrm{z}$ drzewa „W środku ogrodu” próbują się ukryć przed Bogiem. Bóg jednak woła Adama, tzn. zawraca z drogi ku niebytowi. Wszystko, co Bóg dalej czyni, jest ratowaniem człowieka i stworzenia. Jest nim nie tylko obietnica przyjścia Potomka, ale też wygnanie z raju i „przyodzianie” człowieka w „skóry zwierzęce”, cała historia Izraela, ale też i innych narodów. Ostatnie zdania księgi proroka Izajasza mówią o zgromadzeniu wszystkich narodów i języków w Jerozolimie (66, 18-24). We fragmencie tym zawarta jest też obietnica stworzenia nowego nieba i nowej ziemi. Jest to ten sam obraz radosnych losów Wszechświata, który znajdujemy również w Objawieniu św. Jana (rozdz. 21-22).

11 Л. П. Карсавин, dz. cyt., s. 186. 


\section{Nowe stworzenie}

\subsection{Kościół}

Wielu egzegetów wskazuje, że jednym z głównych tematów Ewangelii Jana jest ukazanie Odkupienia jako nowego aktu stworzenia ${ }^{12}$. Uważne przyjrzenie się fragmentowi Ewangelii Jana 1, 19-51 pozwala nawet na wyliczenie sześciu dni ${ }^{13}$. Hexameron Ewangelii Jana ukazuje etapy tworzenia nowego człowieka, od bezradności poznawczej przywódców Izraela - Ludu Wybranego (1, 19-28) do Nowego Adama. Jest nim Nathanael - Prawdziwy Izraelita $(1,47)$, który w Jezusie z Nazaretu, synu Józefa, $(1,46)$ rozpoznaje „Syna Bożego, Króla Izraela” $(1,49)$. Jest to początek jedności świata Niebios i świata „Syna Człowieczego”, czyli Ziemi. Janowy Hexameron kończy się słowami Chrystusa ,zobaczycie niebo otwarte i aniołów Bożych wstępujących i zstępujących na Syna Człowieczego" (1, 51).

Jedność stworzenia, czyli Niebios i Ziemi, tak jak w Ewangelii Jana jedność rodzaju ludzkiego, wewnętrzna jedność człowieka, jest wynikiem Odkupienia. W terminologii Apostoła Pawła wyrazem tej jedności jest usynowienie człowieka przez Boga (Gal 4, 5-6), jest zburzeniem muru dzielącego narody i rozdzierającego człowieka (Ef 2, 14nn).

Myśl tę wyrażają dokładnie słowa kondakionu Dnia Pięćdziesiątnicy: „Gdy zstąpiłeś, mieszając języki (Rdz 11, 7), rozdzieliłeś narody, O Najwyższy, gdy zaś rozdałeś ogniste języki, do jedności wszystko powołałeś: dlatego zgodnie wysławiamy Najświętszego Ducha”.

Ta darowana przez Krzyż i Zmartwychwstanie Chrystusa jedność jest rzeczywistością daną w Kościele. Zmartwychwstały Chrystus jest „ponad wszelką zwierzchnością i władzą, i mocą, i panowaniem, i każdym imieniem, wymienianym nie tylko w tym wieku, ale i w przyszłym”. Bóg „wszystko poddał pod stopy Jego, a Jego samego ustanowił Głową nad całym Kościołem, który jest Ciałem Jego, pełnią Tego, który wszystko we wszystkim wypełnia" (Ef 1, 21-23). Jedność dana w Kościele obejmuje zatem całą ludzkość i wszelkie stworzenie, cały Wszechświat. Jest jednością stworzenia i Stwórcy - Boga Jednego w Trzech Osobach.

Nie ma - pisze św. męczennik (+1929) Hilarion - na ziemi jedności, z którą można byłoby porównać jedność kościelną. Taka jedność znajduje się tylko

${ }^{12}$ C. H. Dodd, The interpretation of the Fourth Gospel, Cambridge 1965.

13 Pierwszy - 1, 19-28; Drugi-1, 29-34; Trzeci-1, 35-39; Czwarty-1, 40-42; Piąty - 1, 43-44; Szósty - 1, 45-51. 
w niebie. Na niebie niezrównana miłość Ojca, Syna i Ducha Świętego jednoczy Trzy Osoby w Jednej Istocie, nie ma trzech Bogów, lecz Jedyny Bóg, żyjący trójjedynym życiem. Do takiej miłości, która wielu mogłaby połączyć w jedno, wezwani są także ludzie. O tym Chrystus modlił się do Ojca Niebieskiego: niech «miłość, którą Mnie umiłowałeś, będzie w nich i bym Ja był w nich» $(\text { Jn 17, 26) })^{14}$.

Eklezjologia ksiąg Nowego Testamentu i teologii prawosławnej jest wielkim apelem do każdego człowieka o myślenie w kategoriach makrokosmicznych i mikrokosmicznych. Jest przypomnieniem o odpowiedzialności człowieka za wszystko, co istnieje. Na Ziemi jest zobowiązaniem - zgodnie z przytoczonym wyżej wyznaniem św. Izaaka Syryjczyka - do troski o wszystkie istoty żywe i o to, co nazywamy materią nieorganiczną, o wodę i powietrze, o glebę i skały.

W świadomości prawosławnej najpełniejszym wyrazem rzeczywistości Kościoła na Ziemi jest Liturgia Eucharystyczna. Jest ona Dziękczynieniem Bogu za Jego Opatrzność, Obecnością Trójjedynego Boga i Modlitwą za wszystkich i wszystko. Ludzie, dzieła ich rąk, budynek kościoła, metal Kielicha i Pateny, Chleb i Wino, każda żywa istota, powietrze i woda, każdy kamień i pyłek - wszystko uczestniczy w tym Spotkaniu Stworzenia i Stwórcy.

\subsection{Bogarodzica}

Kościół widzialny tworzy społeczność ludzi, którzy „uwierzyli w Ewangelię" (Mk 1, 15). Wiara w Ewangelię, czyli w Jezusa jako Wcielone Słowo Boże, jako Boga Zbawiciela, jako Syna Bożego, Jednego z Trójcy Świętej może być udziałem tylko człowieka, który sam podjął taką decyzję. Wiara nie znosi żadnych przejawów niewoli. Chrystus kołacze do drzwi każdego człowieka, wejdzie jednak tylko wówczas, gdy drzwi dla Niego człowiek otworzy (Apok 2, 20). Wiara nie znosi zatem wolności człowieka. To z kolei oznacza potrzebę wytrwałości. Do słuchaczy, którzy Mu uwierzyli, Chrystus mówi: „Jeślibyście wytrwali w Słowie moim, prawdziwie uczniami moimi będziecie" (Jn 8, 31).

W Ewangelii Łukasza znajdujemy trzykrotną wzmiankę o trwaniu lub zachowywaniu w sercu słowa. Po opisie pokłonu pasterzy nowonarodzonemu Dziecięciu Ewangelista zauważa „Maria zaś przechowywała (grec. $\sigma v$ -

14 Священномученик Иларион (Троицкий), Христианства нет без Церкви, Москва 2007, s. 36. 
$\varepsilon \tau \eta \rho \varepsilon l$ - może nieco dokładniej «strzegła») wszystkie te Słowa, rozważając (grec. $\sigma v \mu \beta \alpha \lambda \lambda o v \sigma \alpha$ - współprzyjmowała) je w sercu swoim" (Łk 2, 19). Prawie dokładnie tak samo opisana jest reakcja Bogarodzicy po odnalezieniu 12-letniego Jezusa w świątyni (Łk 2, 51). Ta zdolność Bogarodzicy do „przestrzegania” Słowa Bożego została jeszcze mocniej podkreślona przez Chrystusa w Łk 11, 28. Wielu egzegetów upatruje w tym wierszu odmowę jakiejkolwiek szczególnej czci dla Bogarodzicy. Kościół Prawosławny inaczej interpretuje te słowa. Świadectwem szczególnym i niepodważalnym jest fakt, że fragment Łk 10, 38-42 z dołączonymi do niego wierszami Łk 11, 27-28 jest czytany podczas Liturgii Eucharystycznej we wszystkie święta ku czci Bogarodzicy. Tradycyjna interpretacja tego faktu jest taka, że Chrystus odrzuca możliwość oddawania czci dla Jego Matki tylko ze względu na to, że stała się fizycznie Jego Matką. Jest inaczej, została Jego Matką przede wszystkim dlatego, że jako pierwszy i jedyny do tej pory człowiek nie tylko usłyszała Słowo Boże, ale je też całkowicie wypełniła.

W tym punkcie mamy zdumiewającą zbieżność świadectwa o Bogarodzicy dwóch Ewangelistów, Łukasza i Jana. Św. Łukasz podkreśla odmienność reakcji Bogarodzicy na słowa Archanioła w porównaniu z reakcją kapłana Zachariasza. U Zachariasza była wątpliwość co do możliwości realizacji przepowiedni Archanioła. U Marii jest gotowość do realizacji. W wierszach 2, 19 i 2, 51 Ewangelista Łukasz wyjaśnia przyczynę tej gotowości. Kobieta Maria jest tą Osobą, która inaczej niż Ewa w raju przyjmuje Słowo Boże.

Dokładnie ta sama myśl o Bogarodzicy jest wypowiedziana w innej tylko formie w Ewangelii Jana 2, 1-11. W słowach o braku wina Matka Jezusa prosi Syna o zaradzenie potrzebie człowieka. Jezus mówi, że czas właściwy dla takiej prośby nastąpi dopiero po Jego Godzinie, czyli po Krzyżu i Zmartwychwstaniu $(2,4)$. Kobieta-Matka nie ma ani cienia zwątpienia, że Jej prośba została wysłuchana, nawet jeśli jest przed „Godziną”. W koncepcji teologicznej Ewangelii Jana opowiadanie o weselu w Kanie Galilejskiej jest opowiadaniem o Nowym Raju. W Nowym Raju Kobieta - Nowa Ewa - nie ma najmniejszego zwątpienia w prawdziwość Słowa Bożego i wszystko zostaje restytuowane. Człowiek, przede wszystkim Kobieta, wraca na miejsce, które zostało dla niego w stworzeniu przeznaczone i jeśli ma potrzebę, by woda stała się winem, to tak się też staje, bo to jest już świat stworzenia Bożego.

Obraz restytucji raju w Ewangelii Jana przedstawia w istocie obraz czasów mesjańskich ksiąg prorockich, szczególnie zaś proroka Izajasza 7, 14-27 i 11, 1-9. Głównym motywem tego obrazu jest świętość człowieka i wpływ tego człowieka na całe stworzenie. Obrazy starotestamentowe są niepełne, ograniczają się do kategorii ziemskich. Bo tylko w tych kategoriach mógł myśleć człowiek przed Odkupieniem. Obrazy nowotestamento- 
we przekraczają granice ziemi. Listy Apostoła Pawła są pełne obrazów i terminów filozoficznych, zaczerpniętych z życia religijno-społecznego świata zdominowanego przez hellenizm, dlatego zrozumiałe są dla ludzi w tym środowisku wychowanych. Ewangelista Łukasz pokazuje zbawienie człowieka w ramach historii, tak ważnej dla środowiska syryjskiego i palestyńskiego. Ale kończy wskazaniem sensu historii ziemskiej, którym jest Wniebowstąpienie. Ewangelista Jan dostrzega w historii ziemskiej początek innego świata. „Ten świat” kończy się w chwili Zmartwychwstania. Zamienia się stopniowo w inny świat. Jest to świat, w którym śmierć traci rację bytu. Każdy, kto Słowa Chrystusa „się trzyma, nie skosztuje śmierci na wieki” (Jan 8, 51). Bogarodzica strzegła Słowa Bożego w sercu swoim, dlatego w hymnach ku Jej czci jest opiewana jako „chwalebniejsza od cherubinów i sławniejsza od serafinów", jako Radość wszelkiego stworzenia, bo ukazuje miejsce człowieka w stworzeniu i stworzenie jako całe opromienione światłością Bożą.

\section{God and Creation in Orthodox Theology (Summary)}

The question of the genesis of the world and the attitude of God toward the world is one of the main issues discussed in theology, philosophy, and natural sciences through centuries. The Orthodox Church while answering the question relies on the thoughts of Fathers and Teachers of the Church as well as liturgy displaying spiritual experience of many a generation of saint ascetics much more than other Christian Churches. Asking the question of creation it analyses the views of Origen, Cappadocian Fathers, Saint Basil the Grea, Gregory the Theologian, St. Gregory of Nyssa and further Fathers such as Maximus the Confessor, Symeon the New Theologian, Gregory Palamas. The author of the paper introduces orthodox theology concerning the world and man vewing those realities from two perspectives: before and after the sin, he discusses such issues as the act of creation, human body, ascetiscs, and the responsobility for the creation. The issue of creation is divided between two themes, of the Church and the Mother os God. 